\title{
Træk vedr. Fattig-, Skole- og Kirkevæsen i Graasten 1699-1769.
}

Af Pastor M. H. Nielsen, Skrydstrup.

I.

I Aaret 1686 døde Grev Frederik Ahlefeldt den ældre, Rigets mægtigste Mand næst den enevældige Konge. Efter Griffenfeld var han bleven Storkansler, desuden var han kongelig Statholder i Hertugdømmerne og sad inde med flere andre betydelige Embeder. Saa var han en hovedrig Mand. Det var lykkedes ham atter at faa samlet Slægtens gamle Ejendom $\mathbf{i}$ Sønderjylland, og desuden ejede han store Godser andetsteds $i$ og uden for Riget. Ved hans Død arver den ældste Søn, Grev Frederik Ahlefeldt den yngre, Hovedparten af det sønderjydske Gods, saaledes Søgaard i Kliplev og Graasten i Adsbøl Sogn. Han yndede ligesom sin Fader særlig Graasten, og her byggede han omkring Aarhundredskiftet et pragtfuldt Slot. 1708 dør Grev Frederik barnløs, og Graasten med tilhørende Gods gaar da i Arv til Broderen Karl, der efterhaanden var kommen i Besiddelse af endnu mere Jordegods end nogen tidligere af Slægten. Frederik Ahlefeldt den ældre havde, som han selv sagde, været "en Fjende af verdslig, overflødig Pragt«. Hans to Sønner fik nok ikke uden Grund Skyld for Hang til Ødselhed og Pragtsyge, og de var jævnlig i Pengevanskeligheder. Det gælder især med Hensyn til Grev Karl, om hvern der iøvrigt kunde siges en hel Del godt. ${ }^{1}$ ) I de økonomisk vanskelige Tider, der fulgte med den store nordiske Krig, sank han efterhaanden saa dybt i Gæld, at der tilsidst ikke fandtes den Mand i Landet, "der vilde laane ham en Daler«. Da han døde 1722, blev hans Bo sat under offentlig Administration, og ved en Auktion, som holdtes paa Gottorp i September Maaned 1725, blev det tidligere ahlefeldtske Gods i Sønderjylland spredt for

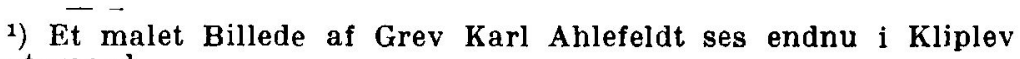
Prastegaard. 
alle Vinde. Graasten og et Par andre Gaarde, der solgtes til Hertug Kristian August af Augustenborg, blev paa en Maade i Slægtens Eje, da Hertugen var gift med en Søster til Frederik og Karl Ahlefeldt. I henved 125 Aar forblev Graasten saa under Augustenborgerne. ${ }^{\mathrm{I}}$ )

I den Del af Adsbøl-Graasten Præstearkiv. der er afleveret til Arkivet i Aabenraa, findes der en gammel Bog i Kvart med et paa Tysk ført Regnskab over en Fattigbloks Indtægter og Udgifter i Tiden fra 1699 til 1769. Af flere i Bogen forekominende Navne fremgaar det, at der maa tænkes paa Fattigblokken i Graasten Kirke eller Kapel. Da Regnskabet er paabegyndt lige efter Nytaar 1699, er Kirken rimeligvis omkring ved den Tid taget i Brug til Gudstjeneste. Slottet blev først færdigt adskillige Aar senere. Det omtalte Regnskab er Hovedkilden til de Træk vedrorende Graastens indre Historie, der skal fremdrages $i$ det følgende.

Regnskabets første Indtægtspost er en Gave paa 60 Rdlr., som den shøjgrevelige Excellence» under 4. Jan. 1699 "til en Begyndelse har lagt i Fattigkassen«. Senere paa Aaret sender Greven gennem sin Forvalter Bentsen endnu 2 Rdlr., der vistnok maa betragtes som et Bidrag til Klinkpungen. I den efterfølgende Tid bestaar Indtægterne udelukkende af de Penge, som lægges i nævnte Pung, der hver Søndag af Degnen bæres rundt ved Gudstjenesten. De indsamlede Penge opbevares i Kirkens Fattigblok eller "Gotteskasten«, der ogsaa undertiden kaldes "Fattigkassen« eller blot "Kassen«. I Marts 1699 betales der 2 Rdlr. for »2 Laase til Fattigkassen«.

I den første Tid efterses Fattigblokkens Indhold næsten hver Maaned, og Regnskabet føres meget omstæendeligt. Denne Nidkærhed slappes snart kendeligt. De forste 4 Aar er Aarsregnskabet underskrevet af tre Mænd: Johs. Weitzmann, Nic. Müller og Præsten i Kliplev Mag. Fr. Joh. Nissen. De 3 følgende Aar er der kun 2 Underskrivere, nemlig Godsinspektør Joh. Weitzmanı og Præsten C. N. Lüders. Sidstnæunte var 1702

1) A. D. Jørgensen, Graastens ældre Hist., Sønderj. Aarb. I. B. og L. Bobé. Slægten Ahlefeldts Hist. VI. B. 
af Greven kaldet til at være Slotspræst $\mathrm{i}$ Graasten og tillige til at være Kapellan hos den gamle Sognepræst i Adsbøl. Gennem mange Aar havde Ahlefeldt'erne holdt en egen Hofpræst paa Graasten. Den sidste var den nævnte Lüders, der 1706 blev kaldet til Præst i Kliplev efter den førnævnte Mag. Fr. Joh. Nissen. For Fremtiden var Stillingen som Slotspræst i Graasten og Sogneprast i Adsbøl forenede i samme Person. Den næstsidste Slotspræst i Graasten var Magister Joh. Paschius. Det er ham, der indviede det nye Slotskapel. Kun een Gang nævnes "Hr. Mag. Pasch" i Regnskabet, i Maj 1701, da han har udbetalt en Understøttelse fra Fattigkassen. Paafaldende er det, at det ikke er harn, men den gamle Præst i Kliplev, der er Medunderskriver af Regnskabet de forste Aar. Det er muligt, at Herskabets Tillid til ham har været mindre god. Hans Liv er ikke ulasteligt. Han stammede fra Ratzeburg i Lauenborg, og hans Skæbne var ret tragisk. I en ung Alder var han bleven Medhjælper ved det filosofiske Fakultet i Wittenberg. To Aar senere, 1687 udnævnes han til Professor i Filosofi ved Universitetet i Rostock, og det følgende Aar bliver han tillige Præst og Provst i det nærliggende Ribnitz. I 1693 bliver han afsat og idømt 3 Aars Tugthusstraf for Sædelighedsforbrydelse og demagogisk Opførsel. Han maa vel være bleven benaadet eller have faaet noget af Straffen eftergivet, da vi allerede 1695 træffer ham som Slotspræst i Graasten. Kun 7 Aar forbliver han her. 1702 bliver han igen anklaget for Sædelighedsforbrydelse og afsat fra sit Embede. Han døde 1709 i Rostock. Endnu 13 Aar efter hans Død svæver der for Domstolene en Sædelighedssag mod ham. ${ }^{1}$ )

I Tiden efter 1706 er det ret sjældent, at Aarsregnskabet er underskrevet. Sker det, er Sognepræsten altid den ene af Underskriverne. Den anden er vistnok altid Godsinspektøren paa Graasten. De to maa vel betragtes som "Fattigkommission" eller Forvaltere af Fattigblokkens Midler. Men de var i

1) Jensen, Versuch einer kirchl. Stat. des Herzogth. Schleswig, 1443, 1447 f., G. Willgeroth, Die Mecklenbl-Schwerinsch. Pfarren I 1791. 
dette deres Hverv i høj Grad afhængige af Godsherskabet. Ofte støder vi paa det Udtryk, at de trufne Foranstaltninger sker "efter Ordre" fra Herskabet, med dettes "Samtykke" eller efter "det naadigste Herskahs Befaling".

Først vil vi nu se lidt paa de Midler eller Indtægter, Fattigkassen raadede over. Vi ser bort fra "Grundfonden" og holder os til det, der indsamledes gennem Klinkpungen. Højest staar Indtægterne det første Aar. Da indkommer der 74 Rdlr. 33\% Sk. Man formoder, at der det Aar har været stor Tilstrømning af Mennesker, der vilde se den pragtfulde Kirke. Det følgende Aar synker Indtægten ned til det halve. De nærmest følgende Aar gaar det atter lidt opad. Det første Tiaar er Gennemsnitsindtægten godt 45 Rdlr. De første Aar efter Grev Karls Overtagelse af Graasten er der en betydelig stigning, men i de sidste Aar af hans Levetid daler Indtægterne stærkt. I de 5 Aar fra 1720 til 24 er Gennemsnitsindtægten nede paa godt 24 Rdlr. Det er ikke blot i Godsregnskabet, man paa den Tid staar over for Underskud. Det samme gælder Fattigkassen. Her er der $\mathbf{i}$ Marts Maaned 1724 et Underskud paa lige ved 40 Rdlr. Efter 3 Aars Forløb er man dog atter kommen paa lige Hamle med Indtægter og Udgifter. Det skete ved en Afkortning eller Indskrænkning af Udgifterne. Denne Sparsommelighed fortsættes i den følgende, augustenborgske, Periode. De aarlige Udgifter er da ofte nede paa en 12-13 Rdlr. Ved den gennem 20 Aar fortsatte Sparsommelighed er man i 1744 naaet frem til et Overskud paa godt 98 Rdlr., og i den følgende Tid tillader man sig større Rundhaandethed. Flere Gange kniber det dog atter med at faa Indtrgterne til at strække til.

\section{Fattigvæsen.}

Hvem var det saa, der nød godt af Fattigkassens Midler? Vi vil vel nærmest tænke paa gamle, fattige eller syge Mennesker, der er bleven trængende. Selv om Understøttelser af den Art forekommer, er de dog - særlig i den første Tid forholdsvis sjældne. Nogle Eksempler skal nævnes. 1709 bliver "en gammel, syg og meget miserabel Kone« betænkt med 
16 Sk., og samme Aar faar "en gammel miserabel Mand" 24 Sk. Da den fattige Maren Kochs i Alnor 1713 brækker Benet, faar ogsaa hun 24 Sk. Flere Gange er der Tale om Begravelseshjælp. Saaledes betales, der $17061 \mathrm{Rd} .5 \mathrm{Sk}$. for en Ligkiste "til den fattige Mand Jørgen Træskomand (Jürgen Treschoman), der er død". Samme Aar faar en Mand i Horskobbel wefter højgr. Excell. Ordre« 32 Sk. til sit Barns Begravelse. 1707 dør Anna Rytters (Rüters) "i stor Fattigdom«. Til hendes Begravelse ydes der 2 Rdlr. - Det maa tilføjes, at Understøttelser af den Art bliver hyppigere efter 1744, da man har opdaget et stort Overskud i Fattigkassen. Det nævnte Aar uddeles der saaledes $30 \mathrm{Rd}$. $32 \mathrm{Sk}$. til 16 fattige i Graasten og $3 \mathrm{Rd}$. til fattige i Adsbal Menighed. 1764 faar 11 fattige i Graasten $14 \mathrm{Rd}$. 4 Sk., mens 12 fattige i Adsbøl maa nøjes med 5 Rd. 36 Sk.

Det maa indrømmes, at Fattigblokkers Bestyrelse - navnlig i len første Tid - mere tænkte paa Børnene eller den opvoksende Slægt end paa de ældre. Allerede 1699 anbringes der "efter Ordre" fra Greven en forældreløs Dreng hos en Mand i Horskobbel for en aarlig Plejeløn af $10 \mathrm{Rd}$. Drengen forbliver her til 1707, da whan er bleven saa stor, at han selv kan fortjene sit Brød." Foruden Plejelønnen betaler Fattigkassen ogsaa jævnlig for Klæder og andre Fornødenheder til Drengen.

Paa samme. Tid - fra Slutningen af 1699 til Begyndelsen af 1706 - tager Fattigblokken sig af to andre Børn, "salig Jens Herredsfogeds« efterladte Drenge Frederik og Karl. Man kunde maaske mene, at "Herredsfoged" er et Tílnavn, Vedkommende har erhvervet sig ved at tjene hos en Herredsfoged. Det kan dog ikke betvivles, at Jens har været virkelig Herredsfoged, eftersom vi i Regnskabet ogsaa støder paa Udtrykket "salig Herredsfogden«. - Det er ikke ualmindeligt i det 18. Aarhundrede at træffe Embedsmænds efterladte blandt dem, der faar Hjælp fra Fattigkassen. Pension var endnu ukendt eller i sin Vorden. Omkring Aar 1700 var Stillingen som Herredsfoged heller ikke saa anset, som den senere blev. Endnu var det som Regel en Bonde, der bekladte Embedet. Antagelig har ogsaa Jens været Bonde. Af Adsbøl Sogns Kirkeregnskaber frem- 
gaar det, at hans fulde Navn var Jens Lousen, og at han aarlig svarede $8 \mathrm{Sk}$. af et Kaad, der tilhørte Adsbøl Kirke. 1699 overdrages nævnte Kaad til Godsinspektør Weitzmann. Rimeligvis er Jens Lousen død samme Aar. Det er sikkert nok over Lundtoft Herred, han har været Foged.

De to Drenge var i Pleje hos Johan Samuel eller "Johan i Smedjen«. I en Beskrivelse over det ahlefeldtske Gods, der skulde sælges ved Auktionen paa Gottorp 1725, siges det, at Smedjen ligger nær ved Slottet. Den er "8 Fag lang og 3 Fag bred.“ Paa det Tidspunkt er Johan Samuel dog ikke længere Smed men Kromand. Han har en Jordlod i Fæste fra Herskabet, og han bor $i$ et Hus, som han har opført sig "for egne Midler«. - Efter ham skal Bakken ved Slottet have faaet Navnet Krobjerg. ${ }^{1}$ )

Naar Johan Samuel fattede Godhed for de to Drenge og tog dem i sit Hus, skyldtes det maaske Slægtskab. Nogen Plejeløn for dem faar han ikke fra Fattigkassen, derimod ydes der ham ret rigeligt til Børnenes Udstyr med Klæder og andre Fornodenheder. Jævnlig foreligger der specificerede Regninger over Udgifter, som Fattigkassen har maattet betale. En enkelt af disse skal her anføres $i$ sin Helhed. Den er fra 1702.

For Klæ, der til sal. Jens IIerredsfogeds 2 Drenge:

\begin{tabular}{|c|c|c|}
\hline$\cdot$ & Rdr. & Sk. \\
\hline $\begin{array}{l}\text { Alen graat Tøj (Klæde, Laken), à Alen } 35 \text { sk. } \\
\text { Alen Baj (Boyen) til Underfoder à } 5 \frac{1}{2}\end{array}$ & 5 & $\begin{array}{c}5 \\
381 / 2\end{array}$ \\
\hline $\begin{array}{l}4 \text { Dusin Zinkknapper, à Dusin } 6 \mathrm{Sk} \text {. } \\
\text { Grua Traad til Knaphullerne }{ }^{2} \text { ) }\end{array}$ & & 24 \\
\hline Skind til Bukser og Camisoler, à Stk. 14 Sk. $^{3}$ ) & 2 & 44 \\
\hline Alen Linned til Underfoder, à Alen 4 sk. & & 40 \\
\hline 4. Dusin Zinkknapper, à Dusin \& Sk.) & & 16 \\
\hline 2 Hatte, à Stk. 19 Sk. & & 38 \\
\hline Alen Linned til 8 Skjorter, à Alen 5 Sk. & 2 & 44 \\
\hline Halsturklæder, à Stk. 51/2 Sk. & & 22 \\
\hline Par Handsker, ì Par $41 / 2$ Sk. & & 9 \\
\hline
\end{tabular}

1) Sønderj. Aarb. I. 40.

2) Alt clet foran navnte er til Frakker, Stortrojer.

3) Det forcgaaende Aar nøjedes man med 9 Fareskind. Naa, Drengene voksede naturligvis. Senere bruges der hver Gang 10 skind. 4) Bliver 1704 til Messing Camisolknapper, à 3 Sk. Dusinet. 
2 Katunshuer, à Stk. 6 Sk. ${ }^{1}$ )

2 Kamme, begge

2 Par Skospænder

2 Par nye Sko, à Par 24 Sk.

4 Par Strømper, à Par 11 Sk.

$\begin{array}{rr} & 4 \\ & 8 \\ & 4 \\ & 44\end{array}$

$1 \quad 16$

Bukser

Endvidere for at udbedre de gamle Klæder

3 Par Træsko til hver for et Aar, à $3 \frac{1}{2}$ Sk.

Summa 19 Rdr. $.13 \frac{1}{2}$ Sk.

Hertil maa lægges 1 Rd. 7 Sk., som Johan Samuel havde lagt ud for Smaafornødenheder til Drengene, bl. a. for $2 \mathrm{Par}$ Vanter eller "uldne Hansker", der kostede 3 Sk. Parret. Det hele beløber sig til 20 Rd. 201/2 Sk. Fuldt saa store er Udgifterne ikke hvert Aar, men de er dog stadig ret betydelige, selv om det jævnlig bemærkes, at man holder sig til "det højst nødvendige«. Man kan dog vanskelig frigore sig for Indtrykket af, at mindre kunde have gjort det. Fra Marts 1700 til Udgangen af 1704 anskaffes der saaledes 4 Gange Bukser og Camisoler af Faareskind. ${ }^{2}$ )

I hvert Fald ser det ud til, at den forældreløse Dreng $i$ Horskobbel - eller hans Plejefader - har stillet mere beskedne Fordringer med Hensyn til Klæder. Fattigkassens Udgifter ti] hans Udstyr overstiger sjælden 2 Rd. om Aaret. Til hans Trøje eller Frakke anvendes der ikke Klæde til 35 Sk. pr. Alen men Vadmel til 7 à $8 \mathrm{Sk}$. pr. Alen. Knapper til Trøjen bliver der ikke Raad til, han maa klare sig med Hægter og Maller for 1 Sk. Han maa nøjes med Bukser af Lærred til 6 Sk. Parret. En enkelt Gang gaar de dog op i 9 Sk. Skindcamisoler, Kamme, Handsker eller Nathuer er der slet ikke Tale om. En Gang betænkes han med et Par Sko til 24 Sk.. Den Lykke falder derimod

\footnotetext{
$\left.{ }^{2}\right)$ Ordet Camisol - paa Fransk Comisole - navnes ofte i ældre Tid, og det bruges til Betegnelse af ret forskellige Klædningsstykker. For det meste var det vistnok en Frakke med mange Knapper i. Her synes det at være en Trøje af Skind. Mens Bukser af Skind eller Læder var almindelige, var Camisoler af Skind vistnok ret sjældne i Sønderjylland.
}

1) Kaldes andensteds "Holl’r (IIüllen) eller Nathuer" (Schlafmützen). 
ret jæunlig $\mathbf{i}$ de to Brødres Lod. Og ofte maa Skomageren reparere deres Støvler. - Muligt er det naturligvis, at Plejeforældrene i Horskobbel har bødet paa Drengens Udstyr. Han fik jo hvert Aar 10 Rdr. i Plejeløn.

En Søster til Frederik og Karl - "Jens Herredsfogeds fattige Pige - bliver 2 Gange betænkt med et Par Sko til 20 Sk. Parret. Ogsaa hun har vel været i Pleje hos en Familie i Graasten.

De første Aar var Udgifterne til Plejeløn ret betydelige. Senere bliver Udgifter af den Art sjældnere, selv om de ikke helt forsvinder. 1710 bliver saaledes "to fattige, nøgne forældreløse Børn" betænkt med 2 Rd. 1739 betales der "efter Ordre" 12 Rd. for en Pige, der opdrages hos Adam Baadfører i Alnor. I de senere Aar forekommer der ogsaa af og til Understøttelse til Plejebørn.

\section{Skolevæsen.}

Fattigkassen sørgede ikke blot for Pleje og Klæder til fattige, forældreløse Børn, den tog sig ogsaa af deres Skolegang. Og det gælder ikke blot nogle faa forældrelose Børn, her strakte man sig videre ud. Det maa erindres, at Omsorgen for den opvoksende Slægts Undervisning paa den Tid ikke var en Sag, som Samfundet, Stat og Kommune tog sig af. Det var en Opgave, som for Størstedelen hvilede paa Forældrene, der selv betalte Lærerne for deres Børns Undervisning. Naar der nu tii Skoleholderen skulde betales en vis Afgift - Skolepenge - for hvert Barn, der nød Undervisning hos ham, forstaar vi, at det undertiden kunde knibe for fattige Forældre at faa deres Børn undervist. Af og til er der private Velgorere, der stifter Legater til fattige Børns Undervisning. Hyppigere sker det dog, at Samfundet træder støttende til gennem Kirkekasse, Fattigblok eller Fattigkasse. Det blev da ogsaa en af de Opgaver, som den i 1699 oprettede Fattigkasse i Graasten tog sig af. Ja, en Tid lang synes det at have været Kassens vigtigste Opgave.

Da Kassen har begyndt sin Virksomhed forst paa Aaret 1699, bliver der snart udbetalt skolemesteren 1 Rd. 4 Sk. for 
Undervisningen af 13 fattige Børn i Januar Maaned - pro informatione Mense Januarii. Inden Udgangen af det forste Aar er Tallet steget til 16. I de nærmest følgende Aar skifter Tallet paa fattige Børn noget, et enkelt Aar - 1703 - er det helt oppe paa 27. - Skolepengene for hvert Barn er en Skilling om Ugen eller 4 Sk. om Maaneden. ${ }^{1}$ ) Men hertil er at bemærke, at der ved Opgørelsen af Regnskabet jævnlig sker Fradrag i den udlovede Sum. Det ser ud til, at der i den forste Tid er holdt ret nøje Kontrol med, om Børnene gav Møde i Skolen eller ej. Udeblev de, skete der næppe Børnene eller deres Forældre nogen Ulempe herfor. Derimod blev Skolemesteren ved deres Udeblivelse straffet paa Pengepungen. Han fik nemlig ingen Betaling for de Dage, Barnet havde forsamt.

I Foraaret 1706 har den ene af Jens Herredsfogeds Drenge forsømt $4 \mathrm{og}$ den anden 5 Uger. Antagelig har det været paa Grund af Sygdom eller anden gyldig Aarsag. Skoleholderen maa herfor give Afkald paa 9 Sk. af $\sin$ Løn. Det var vel nok sjældent, at nogen forsømte Skolen saa længe. Men ofte sker der Fradrag i den Skolemesteren lovede Løn, fordi "nogle har manglet«. I de 16 Uger fra 13. Juni til 3. Okt. 1701 skulde han have haft $5 \mathrm{Rd}$. $16 \mathrm{Sk}$. for 16 fattige Børns Skolegang, men der afkortes $1 \mathrm{Rd}$. - "fordi nogle nu og da er udeblevne«. I de 10 Uger fra 25. Apr. til 3. Juli 1702 tilkom der Skolemesteren 4 Rd. 8 Sk. for Undervisning af 19 fattige Børn, men der fradrages 32 Sk. I dette Tilfælde faar vi noget at vide om Aarsagen til den skete Afkortning. Der er nogle Børn, som har tilladt sig at forsømme Skolen nogle Dage for at kunne "plukke Jordbær«. Om Plukningen er foregaaet ude i Skoven omkring Graasten eller maaske i den vidtberømte Slotshave, om Børnene har plukket til egen eller andens Mund, det faar altsammen staa hen, vist er kun, at Skolemesteren led Tab ved denne Plukken Jordbær.

Saa var der en Grund mere til, at der blev fradraget 32 Sk. i Skoleholderens Løn. Pinsen med dens tre Helligdage er

1) omtrentlig Pris paa et Par Træsko eller $1 / 0$ af Prisen for et Par Lædersko. 
falden i det næunte Tidsrum. Her har Børnene haft tre ekstra Fridage, og af den Grund har man ogsaa ment, at der burde afkortes lidt i Lønnen. Det lader dog til, at det er den eneste Gang, der er foretaget nogen Afkortning paa Grund af Pinsen. Et Par Aar senere - 1705 - sker der en lignende Afkortning for Paaskens Vedkommende. Læreren maa da give Afkald paa Lon for tre Dage. Men ogsaa her lader det til, at der kun denne ene Gang er vist saa stor Strenghed. Derimod maa Skoleholderen næsten hver Jul give Afkald paa Løn for en Uge.

Af Regnskabet fremgaar det, at Skoleferierne hverken har været mange eller lange. Fraset de 8 Dage i Julen, synes de at indskrænke sig til de kirkelige Helligdage, som jo paa den Tid er noget talrigere end nu. Af Sommerferie er der ikke saa meget som en Skygge. ${ }^{1}$ ) Skolemesteren var jo ogsaa økonomisk interesseret $i$, at der blev saa mange Skoledage og saa faa Fridage som vel muligt. Men hænde kunde det naturligvis, at han af en eller anden tvingende Grund matte holde Ferie. Saaledes betales der $i$ de 11 Uger fra 7. Novbr. 1701 til 23. Jan. 1702 kun Skolepenge for 7 Uger - "fordi Degnens Hustru har været syg i 4 Uger«. Man gætter maaske paa, at Skolen er blevet lukket, fordi Sygdommen har været smitsom. Det kan næppe have været Tilfældet, da Manden indenfor samme Tidsrum faar sin fulde Løn som Kirkesanger. Antagelig har han selv maattet pleje sin syge Hustru.

Det er klart, at denne Lønningsmaade ikke er særlig ideel for Skolemesteren. Rimeligvis har han ogsaa arbejdet paa at faa den ændret. Saa meget er vist, at en Reform fandt Sted i Aaret 1709, det Aar, da Grev Karl Ahlefeldt overtog Graasten. Ved Begyndelsen af næunte Aar er Antallet af fattige Børn 16, og i Betalingen for disse fradrages der en Uge paa Grund af Juleferien. Men efter den Tid er Tallet paa fattige Børn hvert Aar og hele Aaret rundt det samme, nemlig 20. Det ser ud til, at man af og til tidligere har slaaet en Streg over Fradragene

1) Den første Hentydning til Sommerferie findes vistnok $i$ en gottorpsk Skoleforordning fra 1733. Her tillades der nvisse Dages Ferie i den store Hede». Rendtorff, Die schlesv.-holst. Schulordnungen, 68 . 
baade ved Forsømmelser og ved Ferier. Det har maaske rettet sig noget efter, om der var Flod eller Ebbe i Fattigkassen. Men for Fremtiden tages der ikke smaaligt Hensyn til Forsømmelser eller Ferier. Hvert Aar udbetales der Skoleholderen 21 Rdr. 32 Sk. for Undervisningen af 20 fattige Born i 52 Uger. Lxreren er med andre Ord kommen paa fast Løn med Hensyn til Undervisningen af de fattige Børn.

Men Herligheden varede kun i 15 Aar. Da der 1724 var stort Underskud i Fattigkassen, maatte man for atter at naa frem til Balance stryge flere af de hidtil afholdte Udgifter. Den største af disse, Posten til de fattige Børns Undervisning, blev helt strøget. $\mathrm{Og}$ der hengaar nu $20 \mathrm{Aar}$, inden man paany faar Raad til at betænke de fattige Skolebørn. Som vi tidligere har hort, opdagedes det 1744, at der var et større Overskud i Fattigkassen, og fra den Tid af begynder man igen at tænke paa fattige Børns Undervisning. Saa langt som før 1724 tør man dog ikke strække sig. Man nøjes med det halve Antal Børn, nemlig 10. I to Aar betales der aarlig Skolemesteren 10 Rdr. 40 Sk. eller 1 Rdr. 4 Sk. pr. Barn. Saa opdages det 1747, at man har spændt Buen lovlig højt, og det aarlige Bidrag pr. Barn nedsættes til 1 Rdr. - „da Fattigkassen ikke formaar ret meget火. Saaledes stod Sagen til 1769.

Fattigkassen betalte ikke blot Skolepenge for de fattige Børn, den tænkte ogsaa paa Bøger til dem. 1702 betaler den saaledes $12 \mathrm{Sk}$. for "3 Katekismusbøger til de fattige Børn, nemlig til Johan Rüborg $2 \mathrm{og}$ til Salig Herredsfogdens 1“. I andre Aar gaar Tallet af købte Katekismer op til det dobbelte. Men det er næsten ogsaa den eneste Bog, der købes til de fattige Børn. Nogle faa Undtagelser er der dog. I Aaret 1700 købes der til "de fattige Børn i Skolen« tvende Evangelia (10 Sk. pr. Stk.), 1 Psalterbog (10 Sk.) og "1 Bog tilligemed en Salmebog" (20 Sk.) For at "forfærdige denne Kirkebog" betales der 10 Sk. - 1702 købes der "til Brug for de fattige Børn i Skolen“ en Regnebog og en Sirach-Psalter-Salmebog. 1706 betales der 16 Sk. for "en Bønne- og Salmebog " til Herredsfogdens Karl. Disse Anskaffelser falder alle i de Aar, da Herredsfogedbørnene søger 
Skolen. Det er muligt, at alle de her nævnte Bøger har været til de to Drenge, der jo synes at have indtaget en begunstiget Stilling.

Den omtalte Regnebog viser, at der er undervist i Regning i Graasten Skole, og at i hvert Fald nogle af de fattige Børn har nydt godt af denne Undervisning.

Mange Vidnesbyrd er der om, at de fattige Børn blev undervist i Skrivning. For selve Undervisningen er der vistnok ikke betalt noget, derimod ydes der Skolemesteren Betaling for $\mathrm{Pa}$ pir og Blæk. I Januar-Februar 1699 betales der 6 Sk. pr. Maaned for Papir og 2 Sk. pr. Maaned for Blæk. Den sidste Post synes at være noget stor sammenlignet med den første. Senere nedsættes da ogsaa Betalingen for Blæk til 1/2 Sk. pr. Uge eller 26 Sk. pr. Aar. Derimod stiger Udgiften til Papir noget. 1703 betales der 2 Rdr. for 1 Ris Papir »til Brug for de fattige Børn i Skolen for et Aar«. Og paa det Standpunkt holder Udgiften sig til 1724.

1699 betales der af Fattigkassen 4 Rdr. 16 Sk. for 1 Bibel og 2 Salmebøger. Her er der vel nok tænkt paa Skoleholderen eller paa Skolen i det hele taget. Der hengaar nu 33 Aar, inden der atter købes en ny Bibel "til Skolen i Graasten«. Men flere Gange er der Tale om Istandsættelse af Bibler. Allerede 1703 betales der 8 Sk. "for Reparation af en Bibel«, og 1708 faar Bogbinderen $20 \mathrm{Sk}$. for at »indbinde Bibelen«. 1716 faar Bogbinderen i Kliplev $16 \mathrm{Sk}$. for at indbinde men gammel Bibel, som tilhører Skolen«. De hyppige Istandsættelser tyder paa flittig Brug af Bibelen.

Paa den Tid, da den nye Slotskirke i Graasten rejste sig, og den til Kirken hørende Fattigkasse begyndte at virke, var der en ny aandelig Retning i Færd med fra Tyskland at bane sig Vej ind over Sønderjyllands Grænser. Da Retningen har fæstet Rod i Sønderjylland, forplanter den sig herfra videre til Kongeriget. Det er den saakaldte Pietisme, der paa mange Maader satte dybe Spor. Det var ikke mindst Tilfældet indenfor Skolen. Man har endog kaldt Folkeskolen for "Pietismens 
Datter «. $\left.{ }^{1}\right)$ Hvor meget berettiget der end kan være i dette Udtryk, maa det dog siges at være for stærkt for Sønderjyllands eller Hertugdømmernes Vedkommende. Her var der ved en af Christian III. i Aaret 1544 udstedt Forordning saavel som ved Forordninger fra forste Halvdel af 17. Aarhundrede lagt Grund til en almindelig Folkeskole. I den af Christian III. udstedte Forordning paabydes der Oprettelse af Skoler paa Landet. Ved disse Skoler skal Kapellanen, Degnen eller Diakonen give Undervisning ikke blot $\mathrm{i}$ den kristelige Børnelardom, men ogsaa i Lasning, Skrivning og Regning. Fattige Børns Skolepenge skal udredes af "Fattigpengene", og "hver Skole skal have sin Bibel og Salmebog af Kirkekassen«. De Lærere, der viser Flid, kan vente Forfremmelse, de forsammelige derimod trues med straf. Sognepresten skal have Tilsyn med Undervisningen. ${ }^{2}$ )

Det voldte dog store Vanskeligheder at faa denne og senere Skolelove førte ud i Livet. Foran har vil set, hvordan det i Graasten kneb med Udredning af Pengene for de fattige Børns Undervisning. Rimeligvis har det ogsaa her knebet med at faa de mere velstillede Forældre til at betale, hvad de skulde. Det var i hvert Fald Tilfældet anden Steds. Saaledes klager - for ut nævne et enkelt Eksempel - „Kirke- og Skoletjenere i Angel og Sundeved « 1674 over, at mange lader deres Børn forsømme Skolen. I den Anledning paalægger en fyrstelig Forordning, der synes at indskærpe tidligere Bestemmelser, Forældrene at holde deres Børn i Skole fra det fyldte 5. til det fyldte 10. Aar samt at udrede de sædvanlige Skolepenge til Skoleholderen, hvad enten Børnene har givet Møde eller ej. ${ }^{3}$ ) Disse og lignende Paabud frugtede næppe ret meget, da de samme Klager stadig møder os.

Et andet Punkt, som ogsaa voldte Vanskeligheder, skal her berøres. Vi tænker paa Tilvejebringelsen af Skolebygninger eller Lokaler, hvori Undervisningen kunde foregaa.

1) Kirkehist. Saml. 5 VI, $241 \mathrm{f}$.

2) Kirkehist. Samf. 3. V. 15்; Schl-Holst.-Lauenb. Kirchen- u. Schulbl. $1885 \mathrm{Nr}$. 47, Rendtorff, Die schl.-holst. Schulordn. 261.

3) Ugeskrift for Skolen 1878 S. 220. 
Fra den Del af Sønderjylland, der hørte under Ribe Stift Torninglen og Enklaverne - hører vi om, at Kirkens Vaabenhus flere Steder gjorde Tjeneste som Skolestue. Saaledes skriver Præsten i Roager Nissenius Nissen 1725, at Vaabenhuset der indtil for nylig er benyttet som Skole for hele Sognets Børn: I en Skrivelse fra Provst Peder Agidius Dahler i Brøns til Biskoppen i Ribe siges der, at "det vester Vaabenhus" ved Kirken i Skærbæk indtil "for nogle Aaringer siden" er benyttet som Skole. Skrivelsen er dateret 13. 11. 1737.') I det lidt sydligere liggende Ballum Sogn, der hørte til Enklaverne, holdtes der lige til 1825 Skole i et paa Kirkens søndre Side liggende Vaabenhus. ${ }^{2}$ ) - Fra det til Slesvig Stift horende Haderslev Provsti har vi talrige Vidnesbyrd om, at der gennem lang Tid er holdt Skole i Kirkernes Vaabenhus eller Sakristi. Det hændte ogsaa, at der var indrettet Skolestue i Kirkens Taarn. ${ }^{3}$ ) Der kan næppe være Tvivl om, at den her omtalte Skik har været almindelig i hele Sønderjylland.

Aar 1693 opførtes der en Skole ved Kirkegaardsporten i Døstrup, og over Skolens Dør blev der sat en Plade med følgende Indskrift: "Det første Skolehus her paa Landet. 1693", Det var den af Pietismen grebne Præst Nissenius Pedersen Wedel, senere tillige Provst for Lø- og Møgeltønder Herred, der havde formaaet sine Sognebørn til at bygge Skolen.") I Aaret 1735 2 Aar før den gamle Provsts Død - skriver Biskop Anchersen, Ribe, $i$ en Indberetning om Skolevæsenet, at der $i$ Døstrup Sogn er 4 Skoler, "som Sognefolket selv har ladet bygge og vedligeholder, lige som de selv underholder og lønner Skoleholderen«. Døstrup Sogn staar vel højest, men tre af Provstiets ovrige Sogne, nemlig Emmerlev, Møgeltønder og det lille Daler Sogn kommer det nær. I hvert af disse Sogne er der 3 Skoler. Ganske vist er der ogsaa inden for det nævnte Provsti nogle Sogne (Randerup, Mjolden og Rømø), hvor man endnu

\footnotetext{
Viborg.

1) De nævnte Skrivelser findes i Ribe Bispearkiv, Landsarkivet i

$\left.{ }^{3}\right)$ Sønderj. Maanedsskr. II, $84 \mathrm{f}$.

3) Sønderj. Aarb. 1931. S. 252 f.

4) Sønderj. Aarb. 1923, S. 210, Sønderj. Maanedsskr. VI, 35 f.
} 
ikke har faaet bygget nogen Skole, men langt værre saa det ud i den nordlige Del af Ribe Stift. Der kunde man flere Steder gennemvandre et helt Herred uden at støde paa en Skole. Naar der i Løbet af 40 Aar er vokset saa mange Skoler frem i den sydlige Del af Stiftet, skyldtes det sikkert i væsentlig Grad Pietismen, som havde slaaet Rod her. ${ }^{1}$ )

Gennemgaaende var Stillingen lysere i Slesvig Stift. Men ogsaa her kunde man undertiden vandre gennem flere Sogne uden at træffe paa en eneste Skole. ${ }^{2}$ ) Egnen omkring Tønder hørte vistnok til de mere fremmelige Dele af Stiftet. Allerede 1721 er der i Tønder Provsti mange Sogne med 3 Skoler, i et Par er der $» 3 \grave{a} 4 \ll$. I det store St. Johannes Sogn paa Før er der endog 6 "Skolehuse«, der alle om Vinteren "er fuldt besat «. ${ }^{3}$ )

Naar det siges, at den 1693 i Døstrup opførte Skole, er »det første Skolehus her paa Landet“, maa "Landet" vel tages i Betydning af Egnen. Vi har Vidnesbyrd om, at der andetsteds 1 Sønderjylland fandtes Skolehuse før den Tid. Saaledes har vi fra Aaret 1639 en Indberetning til Kongen fra Generalsuperintendent Stephan Klotz angaaende Skolevæsenet i Haderslev Provsti. I høje Toner klages der heri over Tilbagegang: Næsten ingen Steder findes der nogen ordentlig Sogneskole. Huse, der før har været brugt til Skoler, er nu solgt og bruges til andet. Han henstiller derfor, at Skolehuse bliver byggede eller forbedrede, og at de Huse, der før har gjort Tjeneste som Skoler, men nu er afhændede, atter kabes tilbage og indrettes til Skoler.4) 1650 udgaar der en kongelig Kundgørelse til Præsterne i Haderslev Amt angaaende Skolevæsenets Forbedring. $\left.{ }^{5}\right)$ Heri paabydes det bl. a., at der i Sognene skal opføres "ordentlige Skolehuse". Særlig store Fremskridt skete der dog nok ikke foreløbig. I lang Tid nøjedes man vistnok her som mange andre Steder med at lade Undervisningen foregaa i

1) Ribe Amtsark., "Forsk. Sager«, Pakke Nr. 9, Viborg. Jfr. "Fra Ribe Amt 1909 . S. 136 f. $453 \mathrm{f}$.

$\left.{ }^{2}\right)$ C. F. Allen, Det d. Sprog i Hertugd. Slesvig el. Sønderj. I $252 \mathrm{f}$.

3) Schriften des Vereins für schl.-holst. Kirchengesch. 2. R. V. B.

Ugeskr. for Skolen 1878, S. $185 \mathrm{f}$.

s) Sønderj. Aarb. 1897, S. 82 f. 
Hjemmene. Enten blev der holdt Skole i vedkommende Skoleholders eget Hjem, eller $i$ et lejet Lokale; eller man lod Skolestuen flytte rundt fra det ene Hjem til det andet.

Vi har en Beskrivelse af Nyherred i det nordlige Angel fra 1723. Deraf fremgaar det, at der i Sognene her fandtes Skolehuse paa 4 til 7 Fag knyttede til Kapellan- eller Degneboligen. Men Ejendomsforholdet til disse Skoler var noget indviklet. Her skal gengives en Beskrivelse af Degneboligen i Store Kværn: "Syv Fag af Sædehuset holdes vedlige af Menigheden og tilhører denne; Resten, som er de 5 østlige Fag, tilhører Degnen. Laden er Degnens. Desuden er der et Skolehus og Bagers, og dette tilhører ligeledes Degnen med Undtagelse af et Fag af Skolen, som tilhører Menigheden og vedligeholdes af denne. $\left.{ }^{1}\right)$ En Snes Aar senere klager samtlige Degne i Herredet over, at Menighederne ikke et eneste Sted har sørget for Skolen. Degnen har tildels selv maattet opfore Skolerne, Menighederne vil knap nok holde dem vedlige. Samme Karrighed lægger sig for Dagen med Hensyn til Degneboligen.")

Vi skal nu se, hvorledes man i Graasten kom til Rette med dette noget vanskelige Spørgsmaal. Allerede 1699 finder vi Skolebygningen omtalt. Selv om det ikke nævnes i Regnskabet, kan der dog ingen Tvivl være om, at Huset tilhører Godsnerskabet, og af dette er overladt Skolemesteren til Bolig og til Skolestue. I den førnævnte Fortegnelse over det ahlefeldtske Gods fra 1725 omtales der nogle "saakaldte nye Huse", der ssom en lille Flække" ligger tæet ved Slottet og er til »ikke ringe Pryd“ for dette. De fleste af disse Huse tilhører Herskabet, og deri har Kirke- og andre Betjente hidtil boet frit. Skolemesteren hører sikkert nok til dem, der har boet frit. Ogsaa hans Hus har vel hørt til de pyntelige.

Selv om Herskabet har overladt Skolemesteren Huset til fri Brug, har det dog ikke ment sig forpligtet til at holde det vedlige eller at sørge for Inventar til Skolen. Her maa Fattigkassen i hvert Fald ofte træde hjælpende til. Nogle Eksem-

1) R. Mejborg, Slesv. Bøndergd. 129 f.

2) Allen, Anf. Skr. I, 257. 
pler herpaa skal anføres. 1699 betales der 32 Sk. for 3 Vinduesbeslag til Skolen. 1710 købes der til Skolen to Tylt Brædder, der betales med 1 Rd. 32 sk. Samme Sum faar Johan Cratz i Snedkerløn, mens Peter Klejnsmed maa nøjes med 24 Sk. for sit Arbejde. Jævnlig omtales der Bænke, Borde, Vinduesrammer, Hylder o. s. v. til Skolen. Der forekommer ogsaa undertiden Udgifter til Vedligeholdelse af Skoleholderens eller Degnens Bolig. Saaledes betales der $171520 \mathrm{Sk}$. for "Reparation af Degnehuset«. Der bliver indsat "nogle Stolper og Tværtræer«, og en Dør laves i Stand. 1722 maa der en helt ny Dør til. Den gaar med Beslag og det hele op i en Rd. Et Par Gange købes der Kalk "til at renovere Huset med". 1724 købes der 150 Mursten til Istandsættelse af Ildstedet. Næsten hvert Aar faar. "Glaseren" Betaling for nye Ruder. Her maa vi vel nok særlig tænke paa Skolestuens Vinduer. Fra 1715 faar Skorstensfejeren Betaling for at rense "begge Skorstene«. Det Arbejde maa Skolemesteren vel selv have sørget for tidligere.

Aaret 1706 har maaske været lidt af et Mærkeaar i Graasten Skoles Historie. Da lejer man hos Mathies Lyszhollm i Flensborg "en Jernkakkelovn" til Skolen. I aarlig Leje skal der svares 36 Sk. 1709 drister $m$ an sig til for en Sum af 7 Rd. at købe "en Jernovn til Skolen" - maaske nok den samme, som man de foregaaende Aar har betalt Leje af. Da der flere Gange er Tale om Rør eller Døre til Kakkelovnen, maa det have været en Vindovn. Bilæggerovne var jo ellers de mest almindelige. Rimeligvis er der her Tale om Skolens første Kakkelovn.

Der skal her fra Nabolaget anfores et Eksempel paa, at man endnu ved Midten af det 18. Aarhundrede kunde stødo paa en Skole uden Kakkelovn. Den laa i Sottrup, en Milsvej nordøst for Graasten. I det hele taget ser det ud til, at Skolevæsenet der ved Midten af det attende Aarhundrede ikke just var i nogen mønstergyldig Orden. Baade de lyksborgske og de reventlov-sandbjergske Beboere her havde $i$ den sidste Tid sendt deres Børn til Skolen i Sottrup, men begge Parter føler sig lige utilfreds med Forholdene. Undervisningen betegnes som 
nover al Maade slet«, og det Skudsmaal, der bliver Skolen til Del, er ikke bedre. Den betegnes som "et aabent Skur eller "en Lade» ved Degneboligen. Den er saa brøstfældig, at Børnene i den er "udsat baade for Vind og Vejr" og "uden den ringeste Beskyttelse mod Kulden«. Nogen Ovn findes der ikke. De lyksborgske Beboere ansøger derfor Hertugen om Lov til paa egen Bekostning at lade opføre en ny Skole paa en Grund, der tilhører deres Husbond. De vil selv forsyne Skolen med Ovn o. 1. Den ansøgte Tilladelse er formentlig givet. I hvert Fald fik de grevelige Bønder samme Aar opført en egen lille Skole paa Grevskabets Grund. $\mathrm{Og}$ den er der stor Glæde over. "De Revenlovske lader alle deres Børn gaa der hen, og dertil med gaar Ungdommen, som for nogle Aar siden er konfirmeret, derhen om Aftenen at lære at læse Breve, at skrive og at regne" - skriver de Sottrup Mænd 1751.1)

Naar man nu var saa lykkelig at have en Kakkelovn i sin Skole, maatte der jo ogsaa Brændsel til. Dette skaffedes i Almindelighed til Veje paa den Maade, at Børnene om Morgenen gav Møde med en Tørv, en Klyne eller et Stykke Træ til Skolens Opvarmning. Helt uden Grund er det vel ikke, naar en vestslesvigsk Præst 1816 betegner denne Maade at skaffe det fornødne Brændsel til Veje paa som "baade ubekvem, utilstrækkelig og uanstændig. $\left.{ }^{2}\right)$ Alligevel holdt Skikken sig længe efter den Tid. Ved en Biskole i Skrydstrup Sogn blev den praktiseret endnu i Halvtredserne i forrige Aarhundrede. At ogsaa Skoleholdere undertiden fører Klage over Fremgangsmaadens Utilstrækkelighed er kun naturligt. Saadanne Klager møder os fra Degne i Nordangel omkring 1740. De udtaler ved samme Lejlighed, at andre Steder kan Bønderne være saa rundhaandede, at de for hvert Barn, de sender i Skole, leverer Degnen et Læs Tørv eller Træ. ${ }^{3}$ ) — Nogen Steder blev der i Stedet for Brændsel in natura betalt Skoleholderen en vis Pengeafgift. Saadan har man tilsyneladende baaret sig ad i Graasten. Da man her i 1744 havde opdaget, at der er rigeligt med Penge $i$

1) Ugeskr. for Skolen, 1878, 3. B. $7 \mathrm{f}$., $20 \mathrm{f}$.

2) Indberetn. fra Pastor Holm, Ballum, Ribe Bispeark, Viborg. Allen, Anf. Skr. I. 257. 
Fattigkassen, tager man den Beslutning at betale Skoleholderen for 10 fattige Børns Undervisning og tillige at udbetale ham "Tørvepenge" for de samme 10 Børn. For hvert Barn betales der 8 Sk. om Aaret. Rimeligvis har de mere velstillede betalt samme Pris for deres Børn. Ret længe staar denne Beslutning dog ikke ved Magt. Kun 3 Aar faar Skoleholderen udbetalt $1 \mathrm{Rd}$. $32 \mathrm{Sk}$. som Brændselspenge for de 10 fattige Børn. I Regnskabet for 1747 støder vi paa en Bemærkning om, at "Tørvepengene for de fattige Børn ikke kan passere." Samtidig bliver, som vi tidligere har hørt, de udbetalte Skolepenge for fattige Børn nedsat fra 1 Rd. 4 Sk. til 1 Rd. aarlig pr. Barn, fordi "Fattigkassen ikke formaar ret meget«. Det er vel nok denne Uformuenhed, der har hindret Fortsæettelsen af den for Skolemester som for fattige Forældre sikkert glædelige Foranstaltning.

\section{Degne og Skoleholdere.}

Stillingen som Degn og som Skoleholder synes hele Tiden fra 1699 til 1769 at have været forenet. Samme Person kaldes snart Degn eller Kirketjener, snart Skolemester eller Skoletjener.

I Regnskabet for 1699 ser vi, at Skolemesteren ugentlig faar udbetalt $10 \mathrm{Sk}$. af Fattigkassen. Senere faar vi at vide, at de 10 Sk. betales for hans Tjeneste i Kirken. Lejlighedsvis siges det, at han faar nævnte Sum udbetalt "for Klinkpungen« eller "for at bære Klinkpungen«. Degnen har med andre ord selv maattet indsamle sin Løn - eller i hvert Fald en Del af denne - ved Gudstjenesten om Søndagen. For hele Aaret beløber Lønnen sig til $10 \mathrm{Rd}$. $40 \mathrm{Sk}$. eller det samme, som han en Tid lang fik for at undervise 10 fattige Børn et Aar.

Godsherskabet sad inde med Kaldsretten saavel til Præsteembederne som til Degne- og Skoleholderembederne paa Godset. Det er en kendt Sag, at det ikke altid var særlig velskikkede Mænd, Godsejerne betroede disse Stillinger. Om de graastenske Degnes Kvalifikationer indenfor det omhandlede Tidsrum foreligger der ingen Oplysninger. Det omhandlede Regnskab giver i hvert Fald ikke saadanne. 
Den Mand, der omkring Aar 1700 sad inde med Degneembedet i Graasten, nævnes slet ikke i Regnskabet. Men anden Steds fra ved vi lidt om ham. ${ }^{1}$ ) Han bar Navnet Hans Mortensen. Midt i Firserne træffer vi ham som Fæstebonde i Stursbøl, Oksenvad Sogn, ved Haderslev. En halv Snes Aar efter, senest 1696, optræder han som Slotsdegn og Skoleholder i Graasten. Det ser vi af nogle Optegnelser, som et af hans Born har efterladt sig. Hvorlænge han beklædte Embedet, ved vi ikke.

Degneparret i Graasten havde to Børn, en Son og en Datter, som begge kom til København og her spillede en betydelig Rolle i det religiøse Røre paa Christian VI.s Tid. De kaldte sig begge med Navnet Martens, der klang noget mere fornemt end Mortensen.

Sønnen Conrad Frederik var som tyveaarig kommen til Hovedstaden, hvor han først var Skriver ved den kongelige Vinkælder. Senere blev han Fuldmægtig forskellige Steder. Til at begynde med sluttede han sig til Pietisterne, men siden knyttes han til Brødremenigheden, hvis Stifter Grev Zinsendorf han kom i personlig Berøring med. En Tidlang var han en af Lederne for Brødremenigheden i Kjøbenhavn, senere bliver han Diakon ved Modermenigheden i Herrnhut, hvor han "blev graa med Are«, og hvor han dør 1765.

Søsteren Marie Martens var et Par Aar yngre. Hun fødtes paa Stursbølgaard 1685. Af hendes senere Gerning fremgaar det, at hun har nydt en god Undervisning i Hjemmet. Med Mund og Pen forstod hun med stor Lethed at give sine Tanker Udtryk baade paa Tysk og Dansk. Som ung havde hun særlig yndet den fromme, tyske Theolog Chr. Skrivers Bøger. Denne Mand havde staaet baade Spener og Francke nær, og han kan betragtes som en Forløber for Pietismen. Allerede 1711 havde Marie Martens »af Kærlighed til Gud og sine danske Venner« oversat hans "Gyldne Bøn-Klenodie" paa Dansk. Selv om det kun er et Udtog af Skrivers »Sjæleskat», var det dog blevet til en Bog paa over 1000 Sider.

1) Kirkehist. Saml. 5, IV, 366 f., 5, V, 417 f., L. Bobé, Johannes Ewalds Levned og Meninger, $233 \mathrm{f}$. 
Ogsaa hun kom tidlig til Kjobenhavn og blev her gift med en norsk Præstesøn Mathias Wulf, der drev en betydelig. Forretning som Bygningsentreprenør. Familien var nær knyttet til Pietisterne, og efter Mandens tidlige Dod blev Marie Wulf en af de ledende Skikkelser indenfor Retningen. Hendes Hus er Samlingssted for de vakte, og med Mund og Pen værgede hun sig og Kredsen overfor de mange Angreb, der rettedes mod dem. Desuden stod hun i livlig skriftlig Forbindelse med Pietister i Ind- og Udland.

I Aaret 1730 blev hendes ældste Datter gift med Præsten ved Vaisenhuset, Enevold Ewald. Han var en Præstesøn fra Højst i Sønderjylland, hvor han havde været med til at bane Vej for Pietismen. I København var han en af Retningens bedste Talsmæend. - I dette Egteskab fadtes 1743 den senere saa kendte Digter Johannes Ewald. Marie Martens er altsaa Bedstemoder og Degnefolkene i Graasten Oldeforældre til Ewald. Det er sikkert nok hans Oldemoder Marine Hansdatter, der ved sin Sygdom i 1701 standsede Skolens Hjul i hele \& Uger. - Gennem de to Børns Liv faar vi ligesom et lille Indblik i Degnehjemmet i Graasten, for ogsaa her gælder vel nok i nogen Grar det gamle Ord, at Eblet ikke falder langt fra Stammen.

I Tiden fra 1727 til 1769 forekommer i Regnskabsbogen Navnene paa tre Degne. De nævnes alle med den franske Titel Monsieur (Mons) — en Titel, som paa den Tid var almindelig for Folk, der havede sig en Smule over den jævne Almue. Den første af dem er Gabriel Jennerich, der allerede 1721 i Kirkebogen nævnes som Degn i Graasten. Rimeligvis har han afløst Hans Mortensen. Skal vi dømme efter de Fingerpeg, Regnskabet giver, har hans økonomiske Kaar ikke været særlig lyse. Vi har tidligere set, at der i en Snes Aar efter 1724 ikke af Fattigkassen blev betalt Skolepenge for fattige Børn. Heller ikke for Papir og Blæk ydedes der mere nogen Understøttelse. Kun et Par Gange støder vi paa smaa Udgifter til Vedligeholdelse af Skolen eller til Anskaffelse af Bænke. Skorstensfejeren faar fremdeles Betaling for at rense Skorstenene, og Glaseren sæetter nye Ruder i. Men det er næsten ogsaa det hele. Fattigkassens 
samlede Udgifter i de Aar overstiger som Regel ikke 13 Rd. Deraf er de 10 Rd. 40 Sk. Degneløn. Gennem flere Aar har Skolemesteren vistnok været Regnskabsfører for Fattigkassen. Under det aarlige Regnskab over Udgifterne støder vi ofte paa Udtrykket "med Tak betalt«. Det ser ud som en Kvittering for Madtagelsen. Underskrift mangler dog.

I Oktober 1734 nyder Degn Jennerich en særlig Gunstbevisning, idet der ekstra udbetales ham 15 Rd. $9^{1 / 2}$ Sk. i Henhold til »det durchlautige naadigste Herskabs mundtlige Consens«. Pengene er anvendt til en ny Kappe. Helt enestaaende er dette Træk dog ikke. 1711 betaler Fattigkassen »efter Ordre fra $\mathrm{Hr}$. Commerce Raaden « ogsaa for en ny Kappe til Degnen. Regningen gik den.Gang dog kun op i $12 \mathrm{Rd} .5^{1 / 2}$ Sk. Maaske har Hr. Jennerich allerede paa det Tidspunkt været Degn i Graasten. Nærmere ligger det dog at tænke paa Hr. Hans Mortensen.

I de sidste Aar af Degn Jennerichs Levetid blev der vistnok gjort lidt for at forbedre hans Kaar. Vi tænker paa "Tørvepengene" og paa, at han nu atter faar udbetalt Skolepenge for Undervisning af fattige Børn. Ret meget har de nævnte Forbedringer dog nok ikke hjulpet. 1741 havde han laant $16 \mathrm{Rd}$. af Kirkekassen i Adsbøl. "Kammerskriver" Simonsen havde givet Løfte om, at Pengene skulde afkortes i hans Lon. Men 6 Aar senere er der endnu ikke sket nogen Afkortning i de 16 Rd., der nok aldrig blev tilbagebetalt. Ved hans Død hører vi, at hans Bo er konkurs. ${ }^{1}$ Af en Slags Kirkebog, der vistnok er ført af Degnen i Adsbøl, fremgaar det, at han 16. Novbr. 1747 blev begravet paa Adsbøl Kirkegaard. Allerede d. 8. Novbr. faar hans Enke af Fattigkassen udbetalt 14 Rd. 15 Sk. - hendes Mands Løn fra 28. Marts nævnte Aar. Desuden gives der hende "naadigst" Løfte om "et halvt Naadensaar". Som Forskud paa Naadensaaret udbetales der hende samme Dag $2 \mathrm{Rd}$.

Ifølge ovennævnte Kirkebog bliver Degnen Hans Schwartz i Adsbøl begravet 29. Maj 1748. Det lader til, at heller ikke hans økonomiske Kaar har været særlig lyse. Blandt de 11 "fattige", der den 9. Marts 1747 faar Understøttelse fra Fattigkassen i

1) Adsbøl Sogns Kirkeregnskabsbog. 
Graasten, er ogsaa "den gamle, udlevede, fattige Degn i Adsbøl". Det er vel nok Hr. Hans Schwartz, der her tænkes kærligt paa. ${ }^{1}$ )

Fra St. Hans Dag 1748 udbetales der Løn til Gabriel Jennerichs Efterfølger, Hr. C. Jacobsen, der i Regnskabet betegnes som "Degn og Organist". Ifølge Kirkebogen begraves han 25. April 1758. Han havde ved sin Død en Del af sin Løn tilgode ved Fattigkassen, der paa den Tid led under Pengeknaphed. Det lader dog til, at Enken efterhaanden fik udbetalt ikke blot Mandens Tilgodehavende, men ogsaa Naadensaaret. De sidste Penge faar hun henimod Udgangen af $\mathbf{1 7 6 0 .}$

Den sidste af de i Regnskabet omtalte Degne er Hr. Tüchsen, der vel nok har tiltraadt Embedet 1758. Det følgende Aar nævnes han i hvert Fald i Kirkebogen som Degn i Graasten.

Hvilken "Tunge« brugte nu de nævnte Degne, naar de sang i Kirken, og naar de talte til Børnene inde i Skolen? Et helt fyldestgørende Svar paa det Spørgsmaal lader sig næppe give ud fra de forhaandenværende Kilder. I Egnen nordfor Flensborg Fjord spores ret tidlig Brydning mellem dansk og tysk Tunge indenfor Kirkens Mure. Det begynder med tysk Gudstjeneste nogle faa Gange om Aaret - ved de store Fester, og naar Godsherskabet holdt Altergang. Senere paanøder man ogsaa den dansktalende Befolkning tysk Gudstjeneste. Klager over, at Modersmaalet bliver tilsidesat, bliver der sjælden laant Øre til. - Denne ringe Sans for Modersmaalets Betydning giver sig et stærkt Udslag hos Ejerne af Graasten Gods - Ahlefeldtslægtens udpræget danske Sind til Trods. Omkring Aar 1700 sad jo Lauenborgeren Mag. Pasch som Slotspræst i Graasten. I de faa Aar, han var her. har han sikkert nok kun prædiket paa Tysk. Fra Tiden omkring 1706 til 1750 var Samuel Thomsen, en Præstesøn fra Flensborg, Sognepræst i Adsbøl og Slotspræst i Graasten. Ogsaa han har vistnok kun holdt tysk Prædiken i Graasten. 1724 klager nogle Bønder i Adsbøl til Kongen over, at de forgæves har bedt Præsten om at prædike

1) Allerede 1702 nævnes Hans Schwartz som Degn i Adsbøl. Hans Forgænger var "Karsten Degn". Kirkeregnskabsbogen. Samme Steds nævnes der 1750 en "Degn Schwartz" i Adsbøl - vel en Søn uf Hans Schwartz. 
paa Dansk. Ved deres Bøn har de kun opnaaet, at han fra Alteret læser Teksterne og Kollekterne paa Dansk, "ligesom der ogsaa undertiden før og efter Prædiken er sunget Dansk«. Til Forsvar for sin Fremfærd anfører Præsten bl. a., at Beboerne næsten kun hørte Tysk ved Hovtjenesten paa Graasten. Det maatte da antages, at de ogsaa kunde forstaa hans Prædiken. Kongen paalægger nu Præsten at betjene sig af det danske Sprog ved Skriftemaal i Kirken og i Hjemmene, hvis ikke han vil udsætte sig for at blive afskediget. Endnu 1735 paastaas det, at der i Adsbøl Kirke kun blev prædiket paa Tysk, "som dog de færreste i Sognet forstaar«. Henimod Slutningen af Aarhundredet er der udelukkende dansk Gudstjeneste i Adsbøl Kirke, og i Graasten Kirke prædikes der paa Dansk hver tredie Søndag. Hvor langt denne Ordning rækker tilbage, ved vi ikke. ${ }^{1}$ )

1725 udtaler Pastor Thornsen, at "det allerede forlængst er blevet anbefalet Degnen (i Adsbøl) at informere Ungdommen i det tyske Sprog, hvilket ogsaa er sket«. Det er muligt, at en lignende "Anbefaling« er sendt Degnen i Graasten. Ogsaa om Skolesproget her tier Kilderne.

Af Fattigkassen blev der jo anskaffet en Del Bøger til Skolen, men vi faar ikke noget at vide om, paa hvilket Sprog de er skrevne. To Gange, 1711 og 16, betales der 24 Sk. for 6 Eksemplarer af v. Støckens Katekisme. Denne Bog - Die vernünftige lautere Milch des heiligen Catechismi - saa Lyset 1672 og var forfattet af den senere Generalsuperintendent Chr. v. Støcken. Den blev gennem lang Tid en af de mest brugte Katekismer i Hertugdømmerne. ${ }^{2}$ ) Ogsaa inden for dansktalende Menigheder blev den almindelig. Poul Sass, Archidiakon ved Mariakirken i Haderslev, havde oversat Bogen, fordi de fleste i hans Menighed er wikkun dansk". Skal de læse Katekismen $i$ et andet Maal, "saa ere de ikke ulige Papegoien. ${ }^{3}$ ) - Da der for det

1) Allen, Anf. Skr. I 196 f. Sønderj. Aarb. I 29, 1905 S. 91 f. Slesv. Provindsialefterr. I 276 f., Schlesw. Holst. Provinzialb. 1792, S. 333.

2) Rendtorff, Anf. Skr. 296.

3) Trykt i Slesvig 1693, i Flensborg 1705 og 1748. Den danske Titel er: "Den hellige Catechismi fornuffige rene Melck». 
meste betales $4 \mathrm{Sk}$. for Stykket, har denne vist været den mest brugte Katekisme i Graasten. Man har dog ogsaa forsøgt sig med andre. 1703 købes der til $8 \mathrm{og}$ de to følgende Aar til 10 Sk. Stykket: Maaske der her er Tale om Haderslevprovsten Bonaventura Rehefelds Teologia Catechetica eller "Undervisning udi voris Christendom i Spørgsmaal og Giensvar saaledes forfattet, at der gives 'Svar ud af $D$. Lutheri lille Catechismo og den Christen Kirckes fornemste og sedvanlige Lof-Sange«, Den var ogsaa oprindelig skreven paa Tysk. ${ }^{1}$ )

Vi har set, at der paa samme Tid fandtes flere Bibler ved Skolen i Graasten. Det er muligt, at Bogen har foreligget paa begge Sprog. Naar de to omtalte Degnebørn fra Graasten syntes at være lige vel hjemme i dansk og tysk Tunge, ligger det nær at gætte paa, at de i Skolen der hjemme har nydt Undervisning i begge Sprog.

\section{Udgifter til Kirken.}

En Gang imellem støder vi paa Udgifter til Kirken. Det er dog gerne ret beskedne Poster. Saaledes anskaffes der 1702 en Lysesaks til 3 Sk. og 1715 en Lygte til 12 Sk.

Af og til støder vi i den ahlefeldtske Tid paa Udgifter til Vin og til "Oblater til Alteret«. Flere Gange or der gjort denne Vedtegning: »da Herskabet ikke er hjemme eller "under det naadigste Herskabs Fraværelse". Hermed indrømmes det jo, at det er Kirkeejernes Pligt at sørge for Vin og Brød til Alteret.

Gennem 5 Aar - fra 1716 til 21 - maa Fattigkassen ogsaa sørge for Vokslys til Alteret. Lysene fornyes to Gange om Aaret, til Jul og til Pinse. Hver Gang medgaar der 8 Pund Voks à 16 Sk Pundet. Det bliver 5 Rd. 16 Sk. om Aaret. Desuden betales der aarlig $4 \mathrm{Sk}$. for "Bomolie og Væge« til Lysene. Vi hører om, at Arbejdet med at støbe Kirkens Vokslys andensteds blev betalt med $\left.1 \mathrm{Mk} .8 \mathrm{Sk} .{ }^{1}\right)$ I Graasten synes man at have været mindre rundhaandet. Antagelig har Degnen eller hans Hustru maattet besørge Arbejdet gratis. Man mindes 1698.

1) Den blev "sjettegang udi Trykken forfærdiget« i Kjøbenhavn

i) I Hostrup Sogn ved Tønder. Sønderj. Maanedsskr. VI. 92. 
Holbergs Ord i Peder Paars om Degnen paa Anholt, der kunde "skønne Vokslys støbe«. - Fra Jul 1721 bliver Vokslysene imidJertid betalt af "den højgrevelige Cassa «, hvorved Fattigkassen befries for en ret betydelig Udgift, der i flere Aar var lagt over paa den. Indtil 1724 betales der dog aarlig 4 Sk. for Bomolie og Væge til Lysene.

Fra 1707 betales der aarlig 2 Sk. for "Kridt til Kirken" "til at skrive Salmerne med". 1738 faar Mester Cratz 24 Sk. "for at lave Tavlen i Kirken sort".

I Regnskabet for 1715 finder vi en noget mærkelig Udgiftspost paa 4 Rd., der er Betaling for Papir, som fra 1708 til 14 "er forbrugt til Kirken". Endvidere siges det, at "Hr. Commerceraaden har approberet, at der for Fremtiden aariig (betales) en Rd. for Papir til Kirken«. I den følgende Tid faar Degnen da ikke blot 2 Rd. aarlig for Papir til de fattige Børn i Skolen, men ogsaa 1 Rd. for Papir til Brug i Kirken. I 1724 falder Betalingen for Papir til Skolen bort, men lige til 1769 betales der aarlig 1 Rd. for Papir til Kirken. Det kunde tænkes, at dette "til« eller »i« Kirken forbrugte Papir er anvendt til "Offersedler". Slige Paamindelser til de offerpligtige møder vi andensteds $i$ det 18. Aarhundrede. De blev vistnok som Regel skreven af Degnen og af ham udsendt til Beboerne. Det ligger dog vist nærmere at tænke sig det omtalte Papir anvendt til "Kirkebøger" eller "Kommunionbøger". Af Kirkeregnskaberne i Adsbøl ser vi, at Degnen der flere Gange faar udbetalt 3 Sk. "für 1/2 Buch Papier $z u$ Annotirung der Beicht Kinder».

\section{Understøttelse til en Udlænding.}

I gamle Fattig- eller Kirkeregnskaber finder vi mange Vidnesbyrd om, at der ogsaa ofte blev tænkt kærligt paa nødstedte Folk eller Institutioner uden for vedkommende Sogns Grænser. Ja, ofte strækker Gavmildheden sig ud over Landegrænsen. ${ }^{1}$ ) - Det ser ud til, at Næstekærligheden i Graasten ikke naaede ud over Sognegrænsen. Naar man her holdt sig til de hjemlige Opgaver, maa Grunden dertil vist søges $i$

1) Jfr. Sønderj. Maanedsskr. II. 88 f., VI 91 f. 
Afhængigheden af Godsherskabet. Man skred vel nødig til Udgifter, der ikke i Forvejen var billigede af Herskabet. -Dog ogsaa her slaar det gamle Ord til, at der er ingen Regel uden Undtagelser. 1713 bliver "en fattig, fordneven luthersk Præst« betænkt med $16 \mathrm{Sk}$. Men det synes ogsaa at være den eneste Undtagelse fra Regelen. 